\title{
KONSEP DAN PENYESUAIAN DIRI PEREMPUAN DALAM PERNIKAHAN PERJODOHAN: Adaptation, Goal Attaintment, Integration, and Latency
}

\author{
Arum Nurcahya \\ Pascasarjana Bimbingan dan Konseling Islam, UIN Sunan Kalijaga Yogyakarta \\ E-mail: arumcerdas@gmail.com
}

\begin{abstract}
Self-concept is how individuals see themselves as individuals which is called selfknowledge. Meanwhile, self-adjustment is the individual's process of forming a harmonious relationship between himself and the environment. With the adjustment, the individual can overcome problems that arise from within and from the environment he lives in. Negative selfconcept implies poor social adjustment because a person's self-concept plays a full role in influencing one's mindset and behavior in interacting with others. The purpose of this study was to determine the concept and adjustment of women in arranged marriage. This research uses qualitative methods with descriptive research type. The subjects in this study only consisted of a woman who had an arranged marriage. The theory used in this research is structural functional with the concept of a systems approach through AGIL (Adaptation; Goal Attainment; Integration; and Latency), namely adaptation to the environment, the existence of goals to be achieved, integration between sub-systems, and maintenance of culture or norms.The results of this study indicate that the subject's idealistic self-concept experiences a shift because it is faced with a determinant external situation that forces the subject to adapt. As for the form of conformity to SA, namely autoplastic, it is shown by being obedient, nrimo and obedient.
\end{abstract}

Keywords: Self and Adjustment,Matchmaking Marriage, Structural Functional Theory

\begin{abstract}
Abstrak: Konsep diri merupakan bagaimana individu melihat dirinya sendiri sebagai pribadi yang disebut dengan pengetahuan diri. Sedangkan, penyesuaian diri yaitu proses individu dalam membentuk hubungan yang selaras antara dirinya dengan lingkungan. Dengan adanya penyesuaian diri, individu dapat mengatasi masalah yang timbul dari dalam diri maupun dari lingkungan yang ia tinggali. Konsep diri yang negative berimplikasi pada penyesuaian sosial yang buruk karena konsep diri seseorang berperan penuh untuk mempengaruhi pola pikir dan tingkah laku seseorang dalam berinteraksi dengan orang lain.Tujuan penelitian ini untuk mengetahui konsep dan penyesuaian diri perempuan dalam pernikahan perjodohan. Penelitian ini menggunakan metode kualitatif dengan jenis penelitian deskriptif. Subjek dalam penelitian ini hanya terdiri dari seorang perempuan yang melakukan pernikahan perjodohani.Teori yang digunakan dalam penelitian ini yaitu stuktural fungsional dengan konsep pendekatan sistem melalui AGIL (Adaptation; Goal Attainment; Integration; and Latency), yaitu adaptasi dengan lingkungan, adanya tujuan yang ingin dicapai, integrasi antar sub-sub sistem, dan pemeliharaan budaya atau norma.Hasil dari penelitian ini bahwa konsep diri idealis subjek mengalami pergeseran karena dihadapkan pada situasi eksternal yang determinan sehingga memaksa subjek untuk beradaptasi. Adapun bentuk penyesuaian diri SA yaitu autoplastis ditunjukan dengan sikap penurut, nrimo dan patuh.
\end{abstract}

Kata kunci: Konsep dan Penyesuaian Diri, Perjodohan, Teori Struktural Fungsional

\section{PENDAHULUAN}

Pada umumnya setiap individu memiliki keinginan untuk melaksanakan pernikahan dan membangun sebuah keluarga bersama dengan pasangannya. Menikah dan hidup berkeluarga merupakan salah satu siklus 
kehidupan terpenting dalam tumbuh kembang hidup manusia. Sebagaimana diungkapkan oleh Hurlock dalam Bonar bahwa menikah termasuk dalam salah satu tugas perkembangan individu (Hutapea, 2011).

Undang-undang Nomor 1 tahun 1974 menjelaskan bahwa dalam pernikahan terdapat ikatan lahir dan batin dari pasangan yang menikah, ikatan lahir adalah merupakan ikatan yang menampak, ikatan formal sesuai dengan peraturan-peraturan yang ada. Sebagai bentuk ikatan yang menampak adalah adanya informasi kepada masyarakat, salah satunya dengan diadakannya pesta pernikahan. Sedangkan ikatan batin adalah ikatan yang tidak nampak secara langsung yaitu merupakan ikatan psikologis. Di mana dalam ikatan ini, suami istri harus saling mencintai satu dengan yang lain, tidak adanya paksaan dalam perkawinan. Kedua ikatan tersebut dituntut dalam suatu perkawinan. Bila tidak ada salah satu, maka akan menimbulkan persoalan dalam kehidupan pasangan tersebut dan biasanya tidak bertahan lama sehingga perceraian sering terjadi (Bahana, 2011).

Pernikahan merupakan sunnatullah untuk kelangsungan hidup manusia, yaitu sebagai awal terciptanya keluarga sebagai tahap pertama dalam pembentukannya, dengan tujuan untuk membentuk keluarga yang bahagia, damai, sejahtera lahir dan batin, sebuah rumah tangga yang penuh limpahan rahmat dan kasih sayang (Hilman, 1990). Terdapat dua jenis pernikahan, yaitu pernikahan atas dasar cinta dan pernikahan yang diatur oleh kerabat atau orang tua yang biasa disebut dengan perjodohan (Habibi, 2015).

Tesaurus sebagaimana dikutip oleh Rizky mengungkapkan pernikahan memiliki banyak padanan kata seperti memasangkan, membaurkan, mempertalikan, mempertemukan, mengawinkan, mengijabkan, menikahkan, menunangkan, menyandingkan, memperantarai, menghubungkan, dan menjembatani. Dapat dikatakan juga bahwa perjodohan adalah proses mengenalkan seseorang kepada lawan jenis melalui perantara, bisa melalui keluarga, teman, ataupun medium lainnya (Kertanegara, 2017).

Setidaknya ada tiga tradisi perjodohan yang ada pada budaya masyarakat Indonesia. Tetapi peneliti hanya mengambil salah satu di antaranya yaitu perjodohan yang terjadi karena tuntutan ekonomi. Biasanya orang tua yang tidak mampu, menikahkan anaknya dengan saudagar kaya agar mendapat penghidupan yang lebih baik. Pihak perempuan, sebagai pihak yang terjodohkan, ada yang menerimanya dengan ikhlas adapula dengan keterpaksaan. Seperti halnya kisah Siti Nurbaya rela menerima perjodohan dengan saudagar kaya bernama Datuk Maringgih demi melunasi hutang orangtuanya meskipun telah menjalin kasih dengan Samsul Bahri. Lagi-lagi, perempuan dalam posisi yang lemah ketika unsur budaya paternalistik (Erlangga, 2013) dan feodalis (Viveers, 2006) masih diterapkan dalam menentukan nasib seseorang sehingga faktor cinta tidak ada di dalamnya (Kertanegara, 2017). Dari studi literatur diketahui bahwa kriteria-kriteria keberhasilan perkawinan 
mempunyai hubungan yang erat dengan adanya cinta dalam perkawinan, di mana cinta merupakan indikator terbentuknya kebahagiaan perkawinan (Indriastuti dan Nur Ainy, 2014).

Individu mendambakan pernikahan yang berhasil, tak terkecuali bagi pasangan yang menikah melalui proses perjodohan. Diperlukan usaha yang lebih dalam mencapai keberhasilan tersebut. Salah satu hal yang penting dilakukan adalah adanya perubahan sikap perilaku demi tercapainya tujuan pernikahan itu. Oleh karenanya menyesuaikan diri dalam kehidupan pernikahan sangatlah penting(Bahana, 2011).

Permasalahan-permasalahan yang muncul dalam proses penyesuaian diri istri yang tinggal bersama suami itu sendiri disebabkan oleh beberapa faktor, salah satunya adalah faktor konsep diri istri. Hariyadi dalam (Nova Annisa dan Agustin, 2012) mengemukakan bahwa konsep diri yaitu bagaimana individu memandang terhadap dirinya sendiri, baik pada aspek fisik, psikologis, maupun sosialnya dapat mempengaruhi proses penyesuaian diri yang dilakukan oleh seseorang.

Pernikahan perjodohan salah satunya terjadi pada Perempuan berinisial "SA". SA merupakan anak ke enam dari tujuh bersaudara sejak kecil dirinya tinggal bersama saudara kandungnya di Jakarta. subjek telah dilatih mandiri semenjak umur 13 sampai 24 tahun dan menemukan pasangan hidup di perantauan, setelah menikah SA beserta suaminya pindah ke kota Cirebon singkat cerita suami dari SA mengidap penyakit gagal ginjal dan meninggal sehingga pada tahun 2011 SA menetapkan untuk pindah ke rumah orangtuanya di Jawa Tengah tepatnya di desa Pekuncen. Lima bulan setelah kematian suaminya, SA dijodohkan oleh kerabat dekatnya dengan seorang yang belum dikenal sama sekali (SA, observasi dan wawancara pada tanggal 28 September 2020, pukul 14.00).

Pertemuan pertama antara suami dan ibu SA dilakukan pada malam hari tepatnya selepas maghrib di kediaman SA, pada waktu itu lelaki yang dikenalkan dengan SA berkunjung untuk menyampaikan maksud dan tujuan akan mempersunting SA. Singkat cerita, SA yang memiliki status "menjanda" meng “iya"kan lamaran dari lelaki yang baru dikenal melalui kerabatnya, karena pada saat itu SA berfikir bahwa saya memiliki dua anak yang masih sekolah sedangkan saya tidak memiliki pekerjaan dan penghasilan yang tetap, sehingga diputuskanlah untuk menikah kembali (SA, observasi dan wawancara pada tanggal 28 September 2020, pukul 14.00).

Tiga bulan setelah perkenalan baik dari pihak wanita dan lelaki barulah diadakan pernikahan, karena lelaki yang dinikahi merupakan perantara dari kerabat SA bukan atas dasar pilihannya sendiri maka SA melangsungkan pernikahan tersebut tidak dilandaskan pada cinta sampai detik ini pun, tidak seperti kebanyakan orang yang melangsungkan pernikahan atas dasar suka sama suka tetapi SA selalu mempertahankan hubungan keluarganya agar selalu harmonis. 
Sikap SA di awal pernikahannya belum bisa menerima dan menjalankan kehidupan rumah tangga dengan setengah hati dan segala perasaan keterpaksaan yang berkecamuk di dalam dirinya. Tetapi, dalam hal penyesuaian diri dengan suami dari pernikahan keduanya mudah dilakukan kemudian konsep diri yang dimiliki ialah menerima dengan catatan di luar mencoba untuk tegar tetapi di dalamnya sangat rapuh sekali.

Kerangkaberfikir AGIL Talcott Parsons akan menjadi pisau analisis untuk mengungkap kontribusi konsep dan penyesuaian diri perempuan dalam kebertahanan rumah tangga atas dasar pernikahan perjodohan. Sebagaimana Talcott Parsons mendefinisikan bahwa teori struktural-fungsional melihat sistem sosial sebagai suatu sistem yang seimbang, harmonis dan berkelanjutan.Talcott Parsons terkenal dengan konsep pendekatan sistem melalui AGIL (Adaptation; Goal Attainment; Integration; and Latency), yaitu adaptasi dengan lingkungan, adanya tujuan yang ingin dicapai, integrasi antar sub-sub sistem, dan pemeliharaan budaya atau norma/ nilai-nilai/ kebiasaan (Puspitawati, 2013).

\section{Pendekatan struktural-fungsional} menekankan pada keseimbangan sistem yang stabil dalam keluarga dan kestabilan sistem sosial dalam masyarakat. Eshleman dkk dalam Harien menyatakan bahwa pendekatan teori struktural-fungsional dapat digunakan dalam menganalisis peran keluarga agar dapat berfungsi dengan baik untuk menjaga keutuhan keluarga dan masyarakat (Puspitawati, 2013).

\section{METODE}

Pendekatan penelitian ini adalah penelitian kualitatif. Bogdan dan Biklen menjelaskan bahwa penelitian kualitatif adalah salah satu prosedur penelitian yang menghasilkan data deskriptif berupa ucapan, tulisan atau perilaku orang-orang yang diamati(Rahmat, 2009). Penelitian ini menggunakan metode penelitian kualitatif dengan karakteristik penelitian Deskriptif. (Best dalam Sukardi, 2004) penelitian deskriptif merupakan metode penelitian yang berusaha menggambarkan dan menginterpretasikan objek sesuai dengan apa adanya.

Wawancara yang akan dilakukan peneliti adalah wawancara model mendalam atau wawancara tak terstruktur (Mulyana, 2005). Dalam hal ini peneliti akan menggali ibu yang berinisial "SA" sebagai subjek penelitian sekaligus sebagai sumber primer terkait cara pandang meliputi penerimaan terhadap diri, pendidikan yang didapat dari orang tua, pengaruh teman sebaya terhadap kepribadian, penyesuaian peran baru, penyelesaian konflik, kemampuan memenuhi kebutuhan, dijodohkan oleh siapa, tipe pernikahan perjodohan, motive pernikahan, kapan informan menikah, fungsi di setiap anggota keluarga, integrasi antar sub-sub sistem, alokasi ekonomi, alokasi politik, alokasi solidaritas.

Observasi adalah pengamatan dan pencatatan secara sistematik terhadap gejala yang tampak pada objek penelitian (Nawawi, 2011). Peneliti mengamati objek penelitian dari kegiatan sehari-hari yang dilakukan oleh subjek. 
Di mana yang menjadi subjek penelitian adalah Ibu "SA" dan objek penelitiannya adalah konsep dan penyesuaian diri perempuan dalam pernikahan meliputi gaya hidup, bertindak dalam berbagai situasi, kecenderungan memberi respon, harga diri individu, hubungan dengan keluarga besar, status sosial, gaya komunikasi.

\section{HASIL}

Mengenai konsep diri ibu SA melalui hasil wawancara, di sini peneliti mempertegas kembali bahwa informan telah membentuk konsep diri sedemikian rupa berdasarkan pengalaman masa lalunya yang selalu disugestikan dalam diri SA bahwa apa yang dia dengar dan rasakan sangat mengganggu alam sadarnya untuk bertindak sesuai dengan apa yang informan kehendaki sehingga alih-alih untuk menstabilkan emosi negatif dari stigma yang menjustifikasi dengan cara mengekang kebebasan diri dalam hak berbicara. Ditinjau dari pernyataan suami dan anak dari SA, dapat diketahui bahwa konsep diri ibu "SA" lebih banyak dipengaruhi oleh pengalamanpengalaman di masa lalunya mengenai kegagalan, penyesalan, dan ketidaktahuannya sehingga kecemasan dalam melakukan sesuatu selalu hadir.

Menurut penuturan subjek, dirinya tidak memiliki kemampuan untuk menghadapi dan menyelesaikan semua masalah yang ia hadapi karena SA merasa pada saat diusia remaja tidak pernah mendapatkan kepuasan atau keberhasilan dan hanya dirundung masalah-masalah pelik yang membuat kondisi batiniah SA sekarang penuh dengan rasa kekecewaan dan trauma yang amat sangat menurut pernyataan dari subjek. Kepercayaan diri pun tidak dimiliki, SA mengaku rasa minder saat berhadapan dengan orang lain seringkali terjadi (SA, observasi dan wawancara pada tanggal 25 September 2020, pukul 14.00). Kekurangan-kekurangan dalam diri subjek tidak bisa diterima berdasarkan penuturannya karena SA beranggapan tidak ingin menyakiti orang lain kemudian tanpa sadar baik dari perilaku dan perkataan berujung sebaliknya.

Adapun penyesuaian diri yang ada pada SA termasuk ke dalam kategori autoplastis. Penyesuaian diri secara autoplastis yaitu penyesuaian yang dilakukan oleh individu dengan suatu lingkungan hidup yang baru baginya dengan cara mengubah dirinya supaya sesuai dengan keadaan-keadaan baru di lingkungannya. Dari ketidakberdayaan dan kelemahan SA dalam pengalaman masa lalunya membuat dirinya menjadi tidak percaya diri untuk memberikan pengaruh yang besar untuk perubahan lingkungan sehingga sikap yang diambil untuk memperoleh titik aman dengan mematuhi dan menginternalisasikan segala norma dan nilai yang ada dalam situasi keluarga yang baru dalam bentuk belanja bersama setiap sebulan sekali dan menerima apa-apa yang dikatakan suami. Penerimaan tersebut berimplikasi pada gaya hidup, pola pikir dan karakter SA. 


\section{PEMBAHASAN}

\section{Konsep diri}

Konsep tentang diri merupakan hal-hal yang penting bagi kehidupan individu karena konsep diri menentukan bagaimana individu bertindak dalam berbagai situasi(Hidayat, 2017) Manusia sebagai makhluk yang diberi anugerah oleh Allah cipta, rasa, dan karsa, sehingga manusia akan berusaha untuk melakukan perbuatan, berupaya untuk memenuhi kebutuhan hidup, sekalipun tidak jarang keinginan atau perbuatan tersebut memiliki implikasi negatif bagi kehidupannya sendiri dan orang lain.

Termasuk seorang perempuan dalam pernikahan perjodohan. Ibu SA mengkonstruksi pemahamannya terhadap realitas yang dihadapinya terkait stigma negatif yang berasal dari kerabat, anggota keluarga dan masyarakat. Dari interpretasinya terhadap realitas tersebut, ditambah dengan dinamika kehidupan yang dijalaninya, ibu SA melakukan sublimasi (meminjam istilah Freud) untuk melakukan pengendapan, perekaman dan pendokumentasian terhadap kehidupannya, serta pengalihan atas kekecewaan terhadap kekurangan diri dengan cara menghukum dan menarik diri dalam bentuk menghemat perkataan saat berhadapan dengan orang lain dan hal itulah yang menghambat dalam proses bersosialisasi (SA, observasi dan wawancara pada tanggal 10 September 2020, pukul 19.30).

Menurut penuturan subjek, dirinya tidak memiliki kemampuan untuk menghadapi dan menyelesaikan semua masalah yang ia hadapi karena SA merasa pada saat remaja tidak pernah mendapatkan keberhasilan dan hanya dirundung masalah-masalah pelik yang membuat kondisi psikis SA sekarang penuh dengan rasa kekecewaan dan trauma yang amat sangat menurut pernyataan dari subjek. Kepercayaan diri pun tidak dimiliki, SA mengaku rasa minder saat berhadapan dengan orang lain seringkali terjadi(SA, wawancara pada tanggal 25 September 2020, pukul 15.45).

Konsep diri merupakan gambaran mental yang dimiliki oleh seorang individu yang terdiri dari tiga aspek yaitu pengetahuan yang dimiliki individu mengenai dirinya sendiri, pengharapan yang dimiliki individu untuk dirinya sendiri dan penilaian mengenai diri sendiri(Hidayat, 2017. Berdasarkan hasil pengamatan peneliti, mengenai aspek pengetahuan yang ada pada ibu "SA" yakni dari segi kuantitas seperti pekerjaan sebagai ibu rumah tangga dan gaya hidup yang dianut sangat sederhana dan apa adanya(SA, observasi pada tanggal 24 September 2020, pukul 20.00).

Aspek yang kedua adalah pengharapan yang dimiliki individu untuk dirinya. Terdapat suatu pernyataan dari ibu "SA" yang berkaitan dengan pengharapan di masa depan, yaitu SA ingin membersihkan nama dengan menampilkan yang terbaik melalui kelebihannya di bidang musik(SA, wawancara pada tanggal 25 September 2020, pukul 15.45).

Aspek ketiga yaitu penilaian terhadap diri sendiri. SA menyadari segala kekurangan yang ada pada dirinya dan sudah mentaksir kejadian yang akan dialami jika dirinya 
melakukan hal-hal yang sekiranya kurang berkenan dalam kacamata orang banyak.

Dari ketiga aspek di atas sudah disadari dan dirasakan oleh SA, artinya dari setiap aspek saling berkesinambungan diawali dari pengetahuan yang dibentuk dari diri sendiri dan persepsi orang lain barulah berbuah pengharapan-pengharapan diri yang ideal untuk 5 tahun yang akan datang atau bahkan dalam kurun waktu yang cukup lama.

Konsep diri idealis dari SA yaitu menjadi istri yang baik dan memiliki karakter yang berbeda dari yang lain namun kondisi yang dihadapainya saat ini membuat konsep yang idealis tersebut bergeser. Kondisi tersebut dikarenakan SA menikah dengan seorang yang tidak dicintai dan suami dari pernikahan keduanya memiliki anak asuh yang seringkali membuat SA merasa jengkel karena pemikiran dan sikap yang kurang dewasa padahal anak tersebut sudah memasuki fase perkembangan dewasa awal. Rekonseptualisasi SA dalam menghadapi kondisi saat ini dalam bentuk memberikan nasehat tetapi sudah jarang dilakukan karena SA lebih menyerahkan kesadaran diri pada sang anak, sesekali memberi teguran melalui perantara suaminya dan SA akan bersikap ramah atau mau tegur sapa jika anak tersebut membantu pekerjaan rumah(SA, wawancara pada tanggal 25 Oktober 2020, pukul 15.45).

Dari beberapa pernyataan SA sudah terlihat bahwa jenis konsep diri yang dimiliki yaitu konsep diri negatif karena salah satu indikator seseorang memiliki konsep diri negatif yaitu tidak bisa menerima kekurangan yang ada pada diri sendiri. Hal tersebut sesuai dengan penjelasan Hurlock dalam Marliana bahwa bila seseorang berkembang dengan konsep diri yang negatif, ia merasa tidak mampu dan rendah diri sehingga memiliki penyesuaian sosial yang buruk. Perasaan rendah diri yang ditandai dengan tidak adanya kepercayaan(Sianturi, 2007). Dari konsep diri yang negatif berimplikasi pada penyesuaian sosial yang buruk karena konsep diri seseorang berperan penuh untuk mempengaruhi pola pikir dan tingkah laku seseorang dalam berinteraksi dengan orang lain.

\section{Pernikahan sebagai ruang penyesuaian diri}

Penyesuaian pernikahan merupakan suatu proses memodifikasi, mengadaptasi dan mengubah individu dan pola perilaku pasangan serta adanya interaksi untuk mencapai kepuasan yang maksimum dalam pernikahan(Dessy dan Matulessy, 2016). Dari pernyataan SA dapat diketahui kondisi subjek setelah ditinggal suaminya yang pertama, banyak sekali hal yang harus dia tanggung sendiri bersama anaknya. Tetapi ada kata yang harus digaris bawahi yaitu "sebelum" ini menandakan adanya perubahan status pribadi dan sosial yang dialami oleh SA(SA, wawancara pada tanggal 25 Oktober 2020, pukul 15.45).

Sesuai hasil wawancara yang dilakukan oleh SA menunjukan adanya pola adaptasi dilihat dari bagaimana SA menjadikan ruang pernikahan sebagai ajang untuk memodifikasi hidupnya. Ada pun efek-efek yang didapat setelah pernikahan di antara keduanya saling 
menguntungkan karena mereka memulai kehidupan baru kembali di usia yang terbilang cukup matang sehingga sudah ada pengalaman terdahulu yang bisa dijadikan parameter.

\section{Skema AGIL Bekerja}

Talcott Parsons terkenal dengan konsep pendekatan sistem melalui AGIL (Adaptation; Goal Attainment; Integration; and Latency), yaitu adaptasi dengan lingkungan, adanya tujuan yang ingin dicapai, integrasi antar subsub sistem, dan pemeliharaan budaya.

Pernikahan dipandang sebagai sistem yang terintegrasi yang membuat satu tatanan menjadi berfungsi. Tentunya fungsi tersebut akan berjalan apabila persyaratanpersyaratannya terpenuhi. Di mana dalam ikatan ini, suami istri harus saling mencintai satu dengan yang lain, tidak adanya paksaan dalam perkawinan. Kedua ikatan tersebut dituntut dalam suatu perkawinan. Bila tidak ada salah satu, maka akan menimbulkan persoalan dalam kehidupan pasangan tersebut dan biasanya tidak bertahan lama sehingga perceraian sering terjadi(Bahana, 2015).

Setiap keluarga mempunyai tujuan yang baik dan mulia misalnya untuk mewujudkan keluarga yang "Sakinah, Mawwadah, Warrohmah" (untuk orang Muslim). Sakinah adalah ketenangan, kehebatan (percaya diri) dan kedamaian. Mawaddah adalah kelembutan tindakan, kelembutan hati, kecerahan wajah, tawadhuk, kejernihan pikiran, kasih sayang, empati, kesenangan, dan kemesraan. Rahmah adalah kerelaan berkorban, keikhlasan memberi, memelihara, kesediaan saling memahami, saling mengerti. Bagaimana bisa SAMAWA? Jika diawal saja sudah banyak situasi eksternal yang gawat.

Skema AGIL merupakan persyaratanpersyaratan yang dapat mendongkrak keharmonisan dan mempertahankan kehidupan rumah tangga dalam perrnikahan perjdohan karena dalam sebuah penikahan yang bukan diawali dari pilihan sendiri seringkali mengalami kegalauan dari awal pernikahan dan bahkan bisa berlangsung dalam kurun waktu yang lama. Agar bertahan hidup maka sistem harus menjalankan keempat fungsi, di antaranya:

\section{Adaptation}

Sebuah sistem ibarat makhluk hidup, artinya agar dapat terus berlangsung hidup, sistem harus dapat menyesuaikan diri dengan lingkungan yang ada, harus mampu bertahan ketika situasi eksternal sedang tidak mendukung. Situasi eksternal yang gawat seperti tidak ada rasa cinta pada pihak SA, ada anak angkat dari pihak suami, konsep diri yang merendah, pasrah, patuh, menganggap diri bodoh sehingga dari semua situasi eksternal yang gawat tersebut dapat melahirkan situasisituasi yang mudah dibodohi, diperintah sesuka hati, selalu dianggap salah serta trouble makeri(Puspitawati, 2010).

Sistem atau keluarga dalam menanggapi situasi tersebut agar tetap bertahan dan harmonis bisa kita analogikan seperti sifat khas bunglon. SA melakukan adaptasi dengan makan bersama dan menjalin keakraban dengan 
sanak saudara dari pihak suami dalam bentuk berkunjung ke rumahnya. Tapi SA melupakan satu hal bahwa dirinya berada di lingkungan yang mempunyai beraneka macam warna. Jika tidak berkaitan dengan kejahatan, seharusnya SA bisa "membunglonkan diri" demi suatu kebersamaan dan keutuhan kekeluargaan.

Termasuk saat di dalam keluarga, SA seharusnya menjadi sosok ibu dan istri pemberi kasih sayang, cinta dan perhatian. Contohnya, suatu sistem atau keluarga akan menyaring situasi eksternal yang gawat seperti rasa cinta belum terakomodasi dengan baik, ada anak angkat dari pihak suami dan dianggap sebagai parasit, konsep diri yang merendah, pasrah, patuh, menganggap diri bodoh yang masuk ke dalam suatu keluarga melalui aturan-aturan yang ada dalam keluarga itu sendiri, antara lain aturan tentang setiap orang harus memiliki tugas di rumah, saling menghargai, mengasihi serta terbuka atas sesama anggota keluarga. Aturan-aturan itu akan mempengaruhi tindakan dalam suatu keluarga.

\section{Goal Attainment}

Sebuah sistem harus mendefinisikan dan harus mencapai tujuan utamanya. Secara estafet ia mengambil hal-hal yang diserap oleh daya adaptasi, diambil oleh goal untuk dimanage sehingga tujuan dapat tercapai. Sistem atau keluarga terdiri dari bapak, ibu dan anak yang interdependensi tentunya memiliki peran dan fungsi masing-masing. Pemimpin dalam kehidupan rumah tangga bagaikan sang nahkoda yang harus membawa kapalnya. Nahkoda yang berarti suami dalam keluarga harus mampu menggerakan seluruh anggota yang ada di dalam suatu keluarga dengan melihat tujuan yang sudah dirancang sedemikian rupa untuk mewujudkan keluarga yang sakinah, mawadah dan rahmah dengan cara berperan sesuai dengan fungsinya masingmasing.

\section{Integration}

Dalam sebuah sistem atau keluarga tentunya ada seseorang yang paling berperan atau memiliki otoritas penuh, suami memiliki posisi stuktural yang paling tinggi dalam sebuah keluarga sebagai kepala rumah tangga untuk dapat membina anggota-anggota yang ada di dalamnya. Untuk dapat mengintegrasikan antar anggota keluarga yang dapat dilakukan dalam teori struktural fungsional yaitu dengan cara sosialisasi. Contohnya, sosialisasi dalam masyarakat, membutuhkan seseorang yang mempunyai posisi struktural yang lebih tinggi daripada masyarakat biasa yang diberikan peran untuk sosialisasi. Hal ini jika kita terapkan dalam keluarga, tentunya peran ayah lah yang memiliki struktur yang paling tinggi di dalam sebuah keluarga agar integrasi selalu dapat terjalin dengan baik diperlukan sosialisasi dengan diimbangi kontrol dalam masingmasing anggota keluarga.

\section{Latency}

Sebuah sistem harus melengkapi, memelihara pola-pola budaya yang menciptakan dan mempertahankan motivasi tersebut. Kebudayaan yang ada pada keluarga SA selalu ditanamkan nilai dan norma yang 
baik seperti sikap menghormati satu sama lain hanya saja menurut pengakuan SA bahwa dirinya kurang diperhatikan oleh orangtuanya pada masa muda dan lebih banyak menyerap ilmu kehidupan dari kaka sepupunya.

Dari kebudayaan tersebut telah membentuk SA berperilaku dan berinteraksi dengan orang lain. Berdasarkan pengalaman SA di masa pernikahan oleh suami pertamanya terdapat sebuah kebudayaan yang humanis di mana masing-masing anggota keluarga saling memberikan kehangatan dan kasih sayang. Tetapi, dalam pernikahannya yang kedua SA dihadapkan pada situasi-situasi yang membuat dirinya mengalami tekanan batin karena bersanding dengan anak angkat dari suami keduanya yang terkadang menjengkelkan karena tidak memiliki pemikiran yang dewasa dan di awal membangun rumah tangga tidak didasarkan atas cinta.

Dari sinilah keluarga SA harus membentuk suatu budaya baru dalam menyikapi hal tersebut dengan menerapkan nilai dan norma. Hal-hal yang sudah dilakukan SA untuk mempertahankan pernikahan tanpa didasari rasa cinta ini di antaranya sebulan sekali ketika gajian, SA beserta suami jalanjalan untuk membeli kebutuhan pokok rumah tangga di toko modern. Menyenangkan anak terakhir dari hasil pernikahan SA dengan suami kedua dalam bentuk membelikan jajan atau barang kesukaan anak. Karaokean di rumah, SA dan suami sesekali bernyanyi bersama menyanyikan lagu pada masanya seperti lagu Broery Marantika, Dewi Yul, dan lain-lain.

\section{SIMPULAN}

Konsep dan penyesuaian diri idealis pada SA sebagai sosok istri yang baik dan memiliki karakter yang berbeda dari kebanyakan orang. Namun, mengalami pergeseran makna karena dihadapkan pada situasi yang membuat dirinya merasa tertekan karena di awal membangun rumah tangga tidak didasarkan atas cinta dan harus bersanding dengan anak angkat dari suami keduanya yang terkadang menjengkelkan. SA menjadi sosok ibu yang tidak memperhatikan dan peduli pada anak angkat dari suaminya. Selanjutnya, yang dimaksud dengan SA ingin menjadi seorang yang memiliki karakter berbeda dari oranglain yaitu sewaktu muda dirinya sangat menyukai bahasa inggris dan sedikit menguasi namun banyak teman-temannya yang tidak tertarik dengan bahasa inggris. Seiring bertambah usia, pengetahuan SA akan bahasa asing perlahan surut karena sudah lama tidak diasah sehingga SA merasa bahwa dirinya tidak punya kemampuan sama seklai. Dari pergerseran konsep diri SA yang semula idealis bertransformasi realistis dalam bentuk SA menjadi wanita penurut, selalu mengalah, saat ada masalah dalam salah satu anggota keluarga, SA lebih memilih untuk diam dengan alih-alih bahwa dari segi ilmu pengetahuan, sosial dan ekonomi lebih unggul pada pihak suami. Sehingga konsep diri SA yang disandingkan pada kondisi realistis pada saat ini berimplikasi pada penyesuaian diri SA yang tergolong autoplatis. 
Rekonseptualisasi dan penyesuaian diri pun harus disesuaikan dengan kehidupaan yang realistik, sikap SA untuk dapat mempertahankan kondisi rumah tangganya tersebut dengan bersikap "pasrah" dengan tujuan menjaga suasana keluarga yang tenteram, hangat, harmonis dan usaha SA berdamai dengan keadaan yang dialami. Sikap "pasrah" di sini berupa kerelaan dan narimo. Dengan sikap "rela" yang dibangun pada diri SA mampu membuat suasana keluarga menjadi tenteram. Rela yang dimaksud SA dalam hal ini yaitu dirinya sudah mensugesti diri bahwa segala sesuatu yang saat ini dia hadapi merupakan skenario terbaik dari sang pencipta. Narimo, menerima segala sesuatu yang berasal dari luar dan yang sudah menjadi bagian dalam hidup SA. Maksud narimo, yaitu SA menerima kondisi yang berasal dari luar seperti status suami dari pernikahan kedua ialah duda beranak dua, dalam hal ibadah seperti sholat 5 waktu dari pihak suami jarang sekali dilakukan, watak pemarah, dan sikap suami SA yang tidak menghormati ibu mertua. Mau tidak mau SA harus menerima semua kondisi tersebut karena sudah menjadi satu di dalam bahtera rumah tangga. Sumbangsih atau kontribusi rekonseptualisasi dan penyesuaian diri pada SA mempengaruhi cara pandang atau pola pikir subjek dalam bersikap.

Pendekatan sistem melalui AGIL (Adaptation; Goal Attainment; Integration; and Latency), yaitu adaptasi dengan lingkungan, adanya tujuan yang ingin dicapai, integrasi antar sub-sub sistem, dan pemeliharaan budaya.
Dari ke empat skema di atas dapat terwujud bilamana latency terpola dengan baik. Latency, yang telah dilakukan SA untuk mempertahankan pernikahan tanpa cinta, yaitu sebulan sekali ketika gajian, SA beserta suami jalan-jalan untuk membeli kebutuhan pokok rumah tangga di toko modern, menyenangkan anak terakhir dari hasil pernikahan SA dengan suami kedua dalam bentuk membelikan jajan atau barang kesukaan anak dan karaokean di rumah, SA dan suami sesekali bernyanyi bersama menyanyikan lagu pada masanya seperti lagu Broery Marantika, Dewi Yul, dan lain-lain.

\section{DAFTAR RUJUKAN}

Annisa, Nova dan Agustin. (2012). Hubungan Antara KonsepDiri Dan Kematangan Emosi Dengan PenyesuaianDiriIstri Yang Tinggal Bersama Keluarga Suami, Jurnal Psikologi Pitutur, Vol.1 No.1 ,Juni 2012. Semarang: Universitas Islam Sultan Agung Semarang

Bahana, O. (2015). Penyesuaian Pernikahan dengan Pasangan dan Makna Pernikahan pada Perempuan yang dijodohkan (Studi Kasus pada Istri yang Menikah Muda di Sumenep). Skripsi. Yogyakarta: Program Studi Psikologi Universitas Sanata Dharma. Diambil darihttps://repository.usd.ac.id/2069/2/1 19114011_full.pdfdiakses pada tanggal 17 September 2020. Jam 16.00 WIB

Christina, Dessy dan Matulessy, Andik. (2016). Penyesuaian Perkawinan, Subjective Well Being dan Konflik Perkawinan. Persona Jurnal Psikologi Indonesia, Vol. 5, No. 01, Januari 2016. Surabaya: Universitas 17 Agustus 1945 
Erlangga, Farera dkk. (2013). Pengaruh Gaya Kepemimpinan Paternalistik Terhadap Motivasi Kerja Pegawai Dinas Sosial dan Tenaga Kerja Kota Padang, Jurnal Humanus, Vol. XII No. 2 Th. 2013. Padang: Universitas Negeri Padang

Habibi, U. (2015). Kepuasan Pernikahan Pada Wanita yang Dijodohkan, Ejournal Psikologi. Vol. 3, No.2, 2015. FisipUnmul. Hariyadi. 1997. Perkembangan Peserta Didik. Semarang: IKIP Semarang Press

Hidayat, F. (2017). Konsep Diri Aktivis Organisasi Pasca Struktural (Studi Kasus Badan Pengurus Harian Pergerakan Mahasiswa Islam Indonesia Cabang Purwokerto Masa Khidmat 2014-2015). Skripsi. Purwokerto: Institut Agama Islam Negeri Purwokerto

Hilman, K. (1990). Hukum Perkawinan Islam. Bandung: Mandar Maju

Hutapea, B. (2011). Dinamika Penyesuaian Suami-Istri dalam Perkawinan berbeda Agama (The Dynamics Of Marital Adjustment in The Interfaith Marriage), Jurnal Penelitian dan pengembangan kesejahteraan social, Volume 16, No. 01. Jakarta: Fakultas Psikologi Universitas Persada Indonesia. Diambil dari:

http://puslit.kemsos.go.id/upload/post/fi les/5ea0dcd4397b53bcc256a8f1ea2586 29.pdf. diakses Tanggal 28 September 2020, Jam: 08.00 WIB

Indriastuti, Ira dan Nawangsari, Nur Ainy Fardana. (2014). Perbedaan Cinta (Intimacy, Passion, Commitment) Ditinjau dari Lamanya Usia Perkawinan pada Istri yang Bekerja. Jurnal Psikologi Industri dan Organisasi. Vol. 3 No. 3, Desember 2014. Fakultas Psikologi Universitas Airlangga

Kertanegara, R. (2017). Perjodohan di Ruang Publik (Studi Resepsi Perempuan Intelektual Terhadap Program Take Me
Out Di Indosiar), makalah ini diunduhhttps://www.academia.edu/404 5688/PERJODOHAN_DI_RUANG_P UBLIK_STUDI_RESEPSI_PEREMPU AN INTELEKTUAL TERHADAP $\mathrm{P}$ ROGRAM_TAKE_ME_OUT_DI_IND OSIAR _ di akses pada tanggal 17 November 2017 pukul 09.55

Puspitawati, H. (2013). Konsep Dan TeoriKeluarga. Artikel. Bogor: PT. IPB Press

Sianturi, Marliana. (2007). Konsep Diri Remaja yang Pernah Mengalami Kekerasan dalam Rumah Tangga. Skripsi. Semarang: Universitas Diponegro 